ВОИСЛАВ САРАКИНСКИ

Университет Святых Кирилла и Мефодия в Скопье

Философский факультет

sarakinski@gmail.com
UDC: $323.1(=293)$

UDK: $94(381)$

\title{
ПОЧЕМУ НЕОБХОДИМО ОСВОБОДИТЬ АНТИЧНЫХ МАКЕДОНЦЕВ ОТ ГРУЗА ИХ ЭТНИЧЕСКОЙ ПРИНАДЛЕЖНОСТИ
}

\begin{abstract}
Аннотация. - Данная статья не исследует были ли античные македонцы эллинами или нет, хотя оспаривается сама концепция дихотомии. Она очень редко имела значение в античное время, но имеет большее значение как инструмент современных историков. Суть дискуссии дистанцируется от традиционных дилемм - что мы знаем о македонцах, были ли они эллинами, имели ли они региональную идентичность - и, с помощью избранных примеров и параллелей остановимся на фактах што, если выберем практичное определение Геродота, используется всеми, мы по сути дела не знаем когда, на каком основании и для кого кто-то является варваром, а кто-то нет. Уже блеклые критерии принадлежности к эллинизму или варварству должны быть отвергнуты, потому что сами эти термины представляют собой подвижную и неравномерную конструкцию; история античной Македонии должна освободиться от напряжения этого вопроса, который долго обрабатывается по несоответствующей методологии.

Ключевые слова: македонцы, эллины, варвары, дихотомия, этнос, конструкт.
\end{abstract}

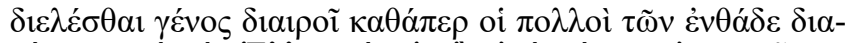

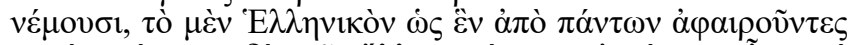

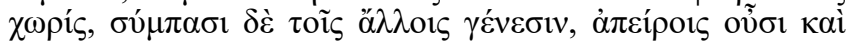

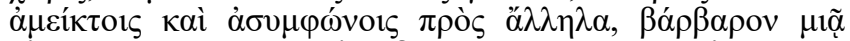

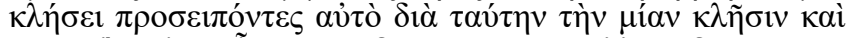

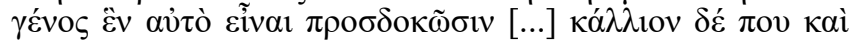

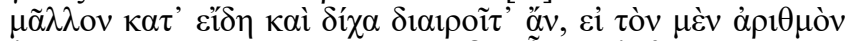

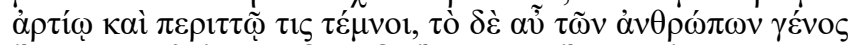

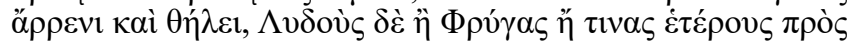

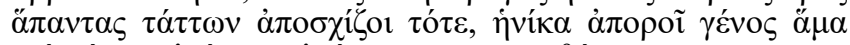

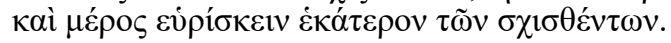

Plat. Pol. 262d, 1-5.

Вопрос о том, были ли македонцы варварами или эллинами (и что для многих важнее - был ли Александр варваром или эллином) нет никакой связи с исторической реальностью. Для тех, которые дискутируют по этому вопросу, обычно им важнее вооружиться фактами, которые подтвердят их собственный нарратив, чем их 
интерес к правильному историческому контексту этих фактов. Ожидаемо, что из этого может родиться только некачественная, даже объективно плохая историография. Далее рассмотрим, почему на такие вопросы никогда не будет удовлетворительного ответа.

1. Есть несколько причин, по которым нет конца дискуссии о том были ли античные македонцы эллинами, и почему научные дискуссии редко остаются в границах науки. Первая причина заключается в том, что в первую очередь, и само понятие “эллин” является неопределенным до такой степени, что ученые до сих пор не могут прийти к единому мнению о том, что он включает в себя и кого именно можно отождествить с ним.

В течение столетий, с древних времен до наших дней, определения понятия “эллин” много раз менялись Начнем с того, что мы не можем определить, когда именно он появился, ни когда точно эта группа людей начала называться общим названием “эллин”. Как обозначение более широкой этнической группы, слово впервые засвидетельствовано надписью, сделанной кем-то Эхемброте, датируемой в 584 г. до н.э. ${ }^{1}$ До этого, слово не имело широкого этнического значения; на пр. у Гомера так именовались лишь жители Фтии в Фессалии, родине мирмидонцев Ахилла. ${ }^{2}$

Что еще хуже, новая эллинская групповая идентичность вообще не вытеснила идентификаторы старой группы. “Эллин” часто считается единственным этническим обозначением, которое эллины использовали для себя. Напротив: Ионяне и Доряне считались полноправными этническими группами, которые также имели общие диалекты, обычаи, культурное и историческое наследие. В источниках встречаем много персонажей, которые ссылаются на разделение ионийского или дорийского, а не эллинского идентитета. ${ }^{3}$ Причина для этого простая. Сегодняшнее представление о нациях, сформированное еще в девятнадцатом веке, сильно отличается от

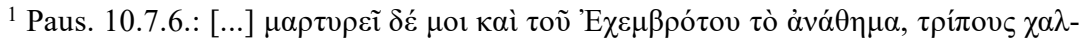

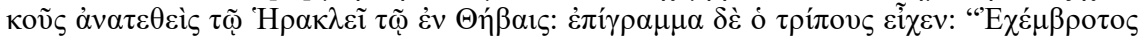

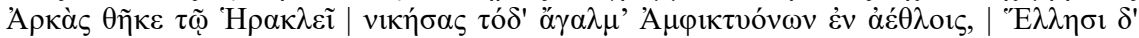

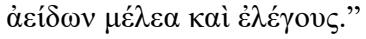

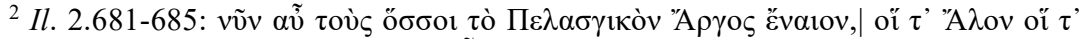

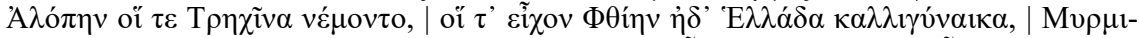

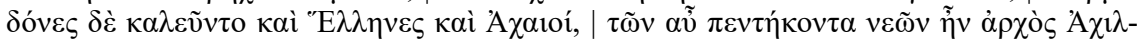

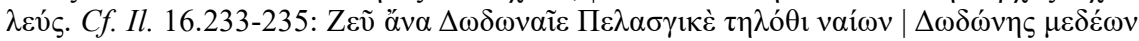

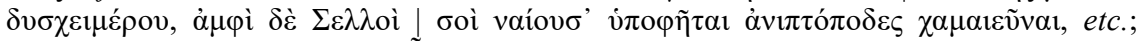

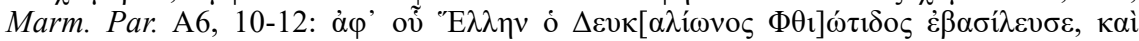
"E

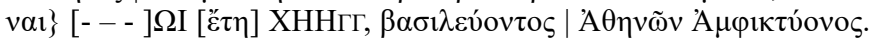

${ }^{3} V$., например, Thuc. 4.61.2.-3, эпизод с речью Гермократа на сицилийском со-

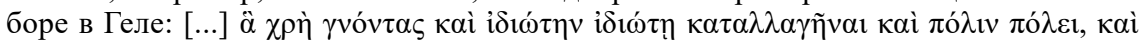

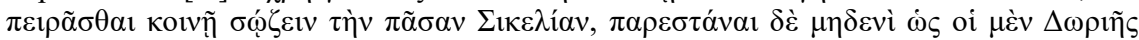

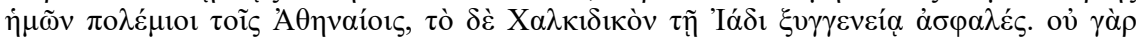

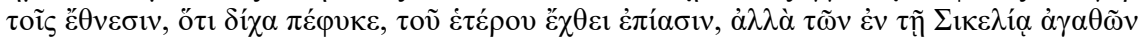

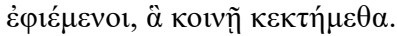


того, как эллины понимали Элладу. В древности не было ничего похожего на то, что современные народы назвали бы «нашей страной». Для эллинов эллинский мир был абстракцией, подобной «христианскому миру» в средние века или так называемому «арабскому миру» сегодня. Поэтому и не удивительно, что отделные личности часто принимали за основу локальную территориальную, политическую и гражданскую идентичност, которая для них была важнее общей; и действительно, источники постоянно рассказывают нам об афинянах, спартанцах, фиванцах, коринфянах и других, реже только об эллинах.

Во время наивысшего подъема Македонии, определению эллинизма предложенному Геродотом - которое мы повторяем до сих пор - было уже более века. ${ }^{4}$ В то время уже было общепризнано, что у эллинов общее происхождение, язык, культура и определенный образ жизни. Но, отложим в сторону Геродота, у эллинов в повседневной жизни не было точных и ясных детерминант эллинизма: не было точного списка условий, которые должны были выполняться, чтобы быть признаными эллинами. Согласно состоянию и необходимости важно было все: происхождение, язык, государственное устройство, религия, участие во эллинских праздниках. Сверх того, эллинизм был представлен во многих региональных вариантах, которые были приемлемы или не в зависимости от автора, его времени и его политических симпатий. ${ }^{5}$ Вследствие такой широты, в зависимости от экономических потребностей и политических целей, появилась возможность бросить вызов эллинизму целых местных групп; ${ }^{6}$ совсем другое дело, насколько это отразилось на

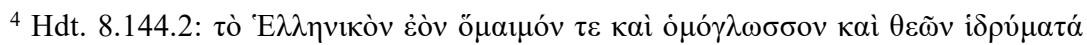

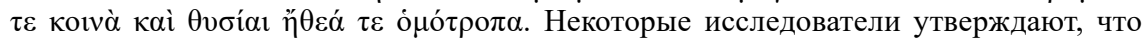
этим определением Геродот только попытался открыто представить политический взгляд, основанный на его собственном интересе. Элементами эллинизма, о которых упоминает Геродот всушность и не покрывается эллинизмом в V веке до н.э. В то время эллины все еще не унифицировали и стандартизировали язык, а религиозная система значительно отличалась одна од другой области, что очень часто вызывало нетерпимость, а не единство. Коцепция о единых эллинских обычаях в большей мере выстроена самим Геродотом, кому была нужна объединеная концепция, чтобы противпоставить чужим “варварским” обычаям персов и скифов. Viz. Hall 2002; Fabrício \& Cunha 2014: 147.

${ }^{5}$ Например, хотя спартанцы, несомненно, принадлежат к эллинскому миру, Геродоту даже удается признать определенные обычаи и традиции, которые были «достойны только варваров» - и, прежде всего, государственную систему. Хартог считает, что изображения королей Геродотом на самом деле являются частью исследования «инаковости», в котором монархия и варварство - два неразделимых понятия. Иностранному монарху свойственна распущенность, склонность к удовольствиям, гордыня, неповиновение закону, физическое насилие и т.д.; мы видим эти почти трагические черты у Писистрата, Периандра и некоторых спартанских царей - но они упоминаются только тогда, когда это полезно для повествования Геродота. V. Hartog 1988: 322-339; Hall 1989: 80 sqq.

6 Эта категория, несомненно, включает антологический отрывок, в котором Фукидид (2.68) говорит о жителях Амфилохии, Амбракии, Хаонии и других соседних 
самих группах, особенно на тех, кто не собирался играть значительную роль на политической арене южных Балкан.

Эллины с классического периода соглашались, что центральное место в этом вопросе занимает единое происхождение, т.е.

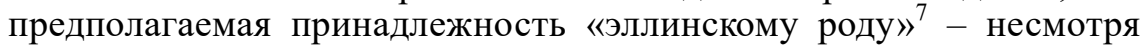
на то, что никто из них не знал своей истории дальше нескольких поколений назад. В отношении своего древнего прошлого у эллинов не было объективных свидетельств и исторических записей, а были этиологические мифы, в которых они объясняли свою древную историю путем богов и героев. Но мифы по своей природе представляют собой смесь изменчивых историй, описывающих неопределенные и непостоянные отношения. Часто случалось, что общественно-политические условия заставляли людей представлять новые утверждения о своем прошлом и тем самым менять большую часть мифических традиций. ${ }^{8}$ Постоянно придумывались новые истории и новые мифические традиции, ${ }^{9}$ особенно для знатных семей и королевских династий.

Большинство аристократов утверждали о своем божественном происхождении, ${ }^{10}$ а короли обычно ассоциировались либо

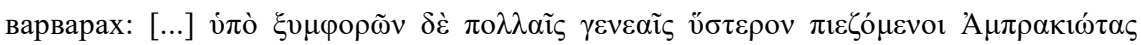

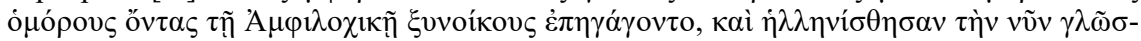

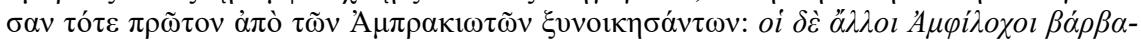

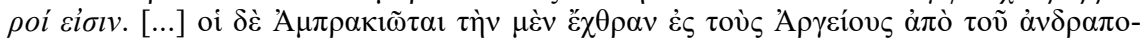

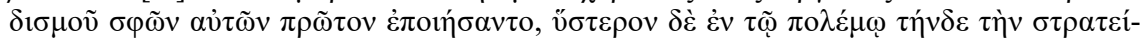

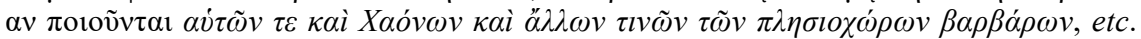

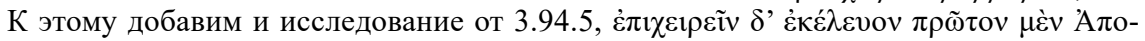

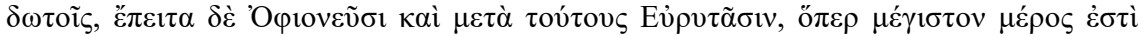

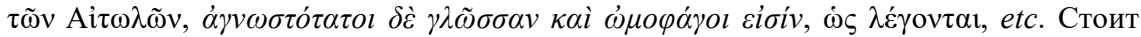
вспомнить например одну афинскую надпись (Tod GHI 2.137 / SEG 15.90; 32.57) в которй Афинское собрание протестует против действий этолийцев, которые «нару-

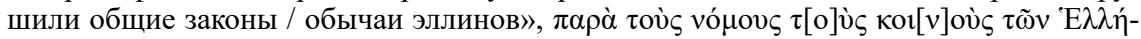

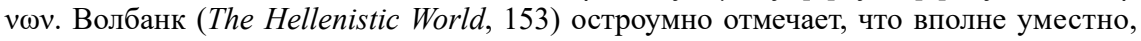
что этолийцы впервые появляются нам в источниках в контексте нарушения общепринятых норм и правил, что они будут делать и в более поздней истории.

${ }^{7}$ В отличие от эллинов в более поздние времена, у которых образование и мировоззрение стояли на первом месте; v. ниже.

${ }^{8}$ Об этой проблеме, $c f$. обязательно Р. Veyne, Did the Greeks Believe in their Myths? An Essay on the Constitutive Imagination. The University of Chicago Press, Chicago, 1988.

${ }^{9}$ Возможно, лучшим примером этого является набор мифических преданий о герое Македоне, который встречается в мифических материалах как сын Зевса, Эола, Ликаона и, наконец, Осириса. По одной версии, его сосед - герой Феспрот (эпоним феспротийцев в Эпире), по другой - его брат Магнит (эпоним Магнитов в Фессалии), и конечно, наиболее интересно то, как после македонского завоевания Египта Македон становится сыном Осириса и брат Анубиса; v. Diod. 1.18, $\tau \tilde{\varphi} ~ \delta$ ' oṽv 'Oбí-

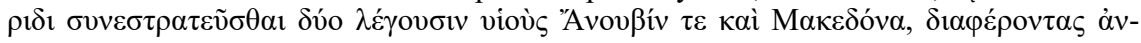

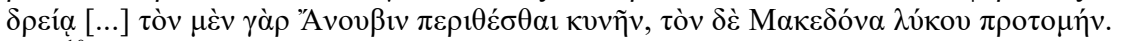

${ }^{10}$ Например, Клисфен и Алкмеониды утверждали, что происходят от правнука легендарного аргонавта Нестора, который сражался с кентаврами; их более широкая родословная, Нелеиды, как говорят, произошла от Нелея, отца Нестора, 
с Гераклом, либо с другим героем из древнейшего (не исторического) эллинского прошлого. Путем таких связей доказывали собственную легитимность, древность рода и важность дома для идентичности всего сообщества. Это было не только допустимо, но также было рекомендовано людям привязать себя к уже существующим историям о происхождении различных племен и социальных групп; Из-за этого в наших источниках - которые уже сохранились не полностью и являются проблематичными - часто непонятно, где заканчиваются реальные семейные связи, а где начинается вымышленная генеалогия. У более мелких сообществ и более слабых политических ассоциаций было только одно политическое оружие преследовать собственную версию своего происхождения и прошлого. С другой стороны, более широкое сообщество, в зависимости от баланса сил и интересов, могло принять или отклонить их долю в сообществе, а иногда и то, и другое одновременно, или в течение очень короткого времени. ${ }^{11}$ В конце концов, сами эллины осознавали, что чей-то статус и место в сообществе зависят не только от его собственных заявлений, но и от того, были ли эти заявления приняты. Если да, то заявитель входит в компанию эллинов; в противном случае он остается вне эллинского сообщества и в источниках отмечен как варвар.

2. Но что на самом деле означает «варвар»? Вторая причина, по которой нашу проблему будет трудно решить, заключается в том, что понятие «варвар» не определено гораздо более четко, чем понятие «эллин». В настоящее время определение означает, что-то примитивное, дикое, грубое или необразованное, что не знаком с цивилизацией, значит общества без технологического развития и культуры. Это современное понимание противопоставляет термин «варвар» термину «цивилизация» - но проблема в том, что наше нынешнее представление о том, что такое «цивилизация», впервые появляется только у французских мыслителей восемнадцатого века. ${ }^{12} \mathrm{C}$ тех пор создается концепция, что люди, живущие в цивилизации, отличаются от варваров потому что они городские, грамотные

который был сыном Посейдона; афинский тиран Писистрат через Солона был потомком Кодра, последнего афинского царя; примеров бесчисленное множество.

${ }^{11}$ Например, hellanodikai в Олимпии как-будто признали Александра I эллином, и позволили ему участвовать в общем эллинском празднике. (Hdt. 5.22., غ̇лє1-

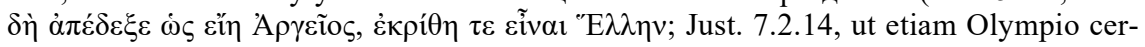
tamine vario ludicrorum genere contenderet); а спартанцы - часть того же более широкого сообщества эллинов - посреди афинского собрания кричали ему вслед, что

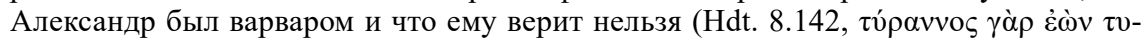

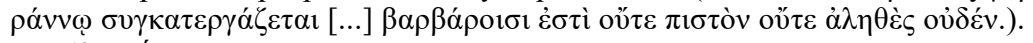

${ }^{12} V$. É. Benveniste "Civilisation. Contribution à l'histoire du mot". Problèmes de linguistique générale, Éditions Gallimard, 1966, 336-345; R. Velkley. "The Tension in the Beautiful: On Culture and Civilization in Rousseau and German Philosophy". Being after Rousseau: Philosophy and Culture in Question. The University of Chicago Press, 2002, 11-30. 
и утонченные, но это понимание не имеет ничего общего с древностью. ${ }^{13}$ Эллины называли варварами почти всех иностранцев, включая персов и египтян, которых мы, конечно, не стали бы называть варварами в современном понимании этого слова.

Интересно проследить развитие представления и отношения к варварам в греческой социальной мысли. Хотя этот термин впервые был упомянут Гомером, ${ }^{14}$ у него по сути дела нет варваров. Ахейцы и троянцы поклоняются одним и тем же богам и имеют одинаковые способы поклонения; живут в городах, не отличающихся друг от друга; на очевидном уровне у них одинаковые обычаи; и на войне они подчиняются одному и тому же героическому кодексу, который в равной степени принимается предводителями двух войск. Троянцы вообще не похожи на «других», а напротив «похожи», если и не полностью одинаковые с ахайцами. ${ }^{15} \mathrm{He}$ знаем, отражает ли такая картина мировоззрение эллинов VIII и VII вв. до н.э., или опять это представление идеи прошлого, прошлого, золотого века героев, похожих и равных друг другу; однако у Гомера полная противоположность и противовес ахейцам - не троянцы, а дикие чудовищные существа, циклопы, амазонки и кентавры, которые находятся за пределами круга людей, отчетливо показывая свою «инаковость». ${ }^{16}$

Многие ученые исследуют способ, которым эта «инаковость» формировалась в глазах эллинов, но также и то, как множество «внутренних» эллинских идентичностей - мирмидонцев, критян, ионцев, дорян, афинян, спартанцев - постепенно превращалось в общую идентичность, но без вытеснения внутреннего множества. ${ }^{17}$ Некоторые считают, что первое испытание эллинского единства произошло в восьмом веке нашей эры, в начале колонизации, с которой они поселились на берегах Средиземного моря «как лягушки вокруг пруда». ${ }^{18}$ Это очень интересно по двум причинам. Во-первых, если это правда, то ростки общей эллинской идентичности, увиденные глазами историка, также появились совсем недавно; и, во-вторых, исследования показывают, что во многих случаях колонисты - которые часто происходили из низших, политически маргинализированных слоев общества у себя дома - создавали колонии в согласии и сотрудничестве с местным населением, поэтому не было ни конфронтации «мы против других», ни «Эллины против

${ }^{13} C f$. Goulart da Silva 2008: 6.

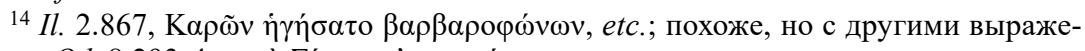

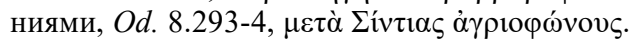

15 Viz. De Luna 2003: 36.

${ }^{16}$ Hall 1989: 47-55; Moggi 2008: 59.

${ }^{17}$ Cf., например, Nenci 1983; Nenci 1990; Hall, 1989; Hartog 1996; Hall 1997; Malkin 1998; Malkin 2001; Hall 2002; Moggi 2008, и много других.

${ }^{18}$ Plat. Phaed. 109a-b. 
варваров». ${ }^{19}$ Согласно Геродоту, настоящее отделение от варваров и вообще от Востока, ${ }^{20}$ который раньше был экзотическим объектом восхищения и источником необычных знаний, а теперь превратился в barbaricum, произошло с греко-персидскими войнами, когда эллины якобы объединились, чтобы защитить Элладу от азиатских варваров. Но и это утверждение является проблематичным, потомучто эллины боролись против персов, чтобы воспрепятствовать попасть под власть тирана, самодержца и чужого царя; их язык, культура и мировоззрение не подвергались опасности. На основе опыта с малоазийской Ионией, эллины хорошо знали, что жизнь под властью персов означала не угнетение культуры, а просто уплату налогов - форму угнетения, которую и Афины позже наложили на многие эллинские города. ${ }^{21}$

От Эсхила и Геродота, через трагиков и афинских ораторов до Аристотеля и стоиков, мы можем проследить изменения в понимании о том, что не эллин, а что варвар, обусловленные историческим контекстом и эллинской политической идеологией. ${ }^{22}$ Вершиной этого процесса находим у Аристотеля, на котором, возможно, больше всего основывается эллинское высокомерие и презрение к варварам; но отражают ли записи Аристотеля общепринятое мнение эллинов? То, что философ из Стагиры пишет в своей «Политике» тексте, который впоследствии действительно станет очень влиятельным - это лишь позиция или идея уважаемого человека в данный исторический момент в IV в. до н.э.; Нам ничего не известно о взглядах обычного грека из Акарнании, Фокиды, Беотии или Фессалии.

3. Мы уже прочитали достаточно, чтобы понять, что во многих случаях - даже в источниках того времени - грань между эллинами и варварами не только не четко проведена, но размыта почти до бессмыслицы. Столь же абсурдно спрашивать и спорить о том, кто был или кто не был греком, и стала ли определенная группа людей частью другой группы людей в контексте той этнической принадлежности, которую мы понимаем сегодня. ${ }^{23}$ И все же история

${ }^{19}$ Nenci \& Cataldi 1983: 582; Hall 1989: 8-13, 47-55; Hall 2002: 97-124; Moggi 2008: 55.

${ }^{20} C f$. общий показ Fabrício \& Cunha, 2014: 146, обзор литературы.

${ }^{21}$ Goulart da Silva 2008: 7.

$22 V$. обязательно Isaac 2017, который дает подробный обзор понятия «варвар» в эллинской и римской литературе.

${ }^{23}$ Поэтому вместо «этнической принадлежности» многие современные антропологи, социологи и историки античности предпочитают одно новое новосозданное понятие «этницитэт». В отличие от этнической принадлежности, которая имеет все отличия абсолютной категории, этницитэт скорее покрывает самосознание того, что кто-то принадлежит к определенной этнической группе, и вовлекает несколько этнических групп в социальное взаимодействие друг с другом. Большинство современных исследователей согласны с тем, что этническая и культурная идентичность, а также этническая принадлежность, упоминаемая как самосозна- 
древних македонцев постоянно омрачается этим самым вопросом, как если бы он разрешил все сомнения и пробелы в исторических источниках. В ситуации, когда мы почти ничего не знаем о политической и социальной истории областей Верхней Македонии, когда получаем единственное объективное знание из материальных источников, а Македонию до Александра знаем исключительно из работ внешних источников, которые имеют дело с историей их собственной политической сцены - в научном мире акцент делается на этнической принадлежности македонцев, хотя мы видим, что такой вопрос, поставленный таким образом, не получит ответа, который удовлетворил бы современного человека.

Эпизоды из древних источников, которые касаются этого вопроса рассказывались и интерпретировались много раз, поэтому нет никакой необходимости повторяться. Вместо этого дадим небольшой обзор, в котором рассмотрим методологические спорные и больные точки этого дистопичного вопроса.

Дискуссия о том, являются ли античные македонцы частью античных эллинов, (а вместе с тем и очень важный вопрос: был ли Александр Великий эллин!) вращаются, в основном, вокруг группы отрывков из текстов классических авторов, которые имеют беглую, недореченную и двусмысленную природу, предлагая аргументы при помощи которых можно подкрепить, и одну, и другую сторону. Мы только что упомянули, что большая часть наших объективных знаний поступает из материальных источников. Но этническая принадлежность, в форме самоосознания принадлежности, является социальной конструкцией и вряд ли может быть обнаружена с помощью археологических находок; ${ }^{24}$ письменные источники попрежнему играют ключевую роль в этом вопросе. В доступных нам источниках данные по Македонии начинаются с Геродота и Фукидида, в V веке до н.э..

ние, являются социальными и приобретенными, а не врожденными конструкциями. Об этой проблеме, v. J. Engels 2010: 82, с дополнительными пояснениями.

24 Бесспорно, что археологические раскопки македонских одиночных могил и некрополей, городов, храмов и дворцов, предоставляют новые и интересные данные. Однако ученые не уверены, что могут ответить на основные вопросы о македонской этнической принадлежности и идентичности только - или в первую очередь - на основе археологических находок и материальных следов населения древней Македонии. В последние десятилетия появляются все новые и новые надписи из Македонского царства и соседних областей; они являются желанными дополнительными источниками для многих деталей македонского общества, но редко говорят нам что-либо о македонской этнической принадлежности идентитете. Об этой проблеме, v. P. J. Rhodes, "The Literary and Epigraphic Evidence to the Roman Conquest". In Joseph Roisman \& Ian Worthington (eds.), A Companion to Ancient Macedonia, Wiley-Blackwell, 2010, 23-40. То же самое относится и к легендам и иконографиии македонских монет: v. K. Dahmen, “The Numismatic Evidence", в том же издании. 
Геродот утверждает, что у него есть доказательства того, что македонский королевский дом имел эллинское происхождение. То, что он предлагает в качестве доказательства, довольно распространено: после некоторых раздумий среди судей Олимпийских игр Александр I был освобожден для участия в соревнованиях, потому что он доказал, что его семья родом из Аргоса. Вполне возможно, что эта генеалогия была бессмысленной с самого начала, потому что в древности генеалогии использовались не для исследования и изучения собственного прошлого, а для доказательства того, какой дом и какой род имел более славное и знаменитое происхождение. Некоторые эллины, включая и Геродота, по какой-то причине были готовы поверить в Александра I - хотя Геродот нигде не отвечает на вопрос, почему из всех собравшихся соперников только Александру пришлось доказывать, что он эллин. В самом деле, если македонцы считались эллинами - и если все эллины приветствовались на Олимпийских играх - почему только Александру было нужно доказывать его эллинское происхождение?

Через столетие позже, Исократ подтверждает историю Геродота как хорошо известный факт; напротив, Демосфен без всяких колебаний называет и Филиппа II, и македонцев варварами, не заслуживающими особого уважения. ${ }^{25}$ Но это не дает никакого ответа на вопрос, были (или считались) ли македонцы эллинами или варварами. В научных дебатах обычно забывают, что включение и исключение из группы, которая называла себя «эллинами», были важны, потому что, по сути, и обвинения, и суждения в том или ином направлении были политическими решениями. Помимо прочего, эллинизм был надежным политическим инструментом. Александр I пытался доказать, что он эллинского происхождения, не для участия в олимпийских гонках, а для того, чтобы его приняли в элитную торговую и политическую сеть (более) известных сообществ в восточном Средиземноморье. Его королевство располагалось на крайней северной периферии Эгейского мира; поэтому, он хотел воспользоваться связью с эллинской культурной зоной, ее торговыми контактами и политическими союзами. Суть всей истории вовсе не в происхождении Аргеадов, а именно в интересах Македонии; а подозрения эллинов - признак того, что они не были в настроении дать македонскому царю то, что он просил. ${ }^{26}$

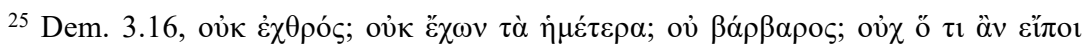

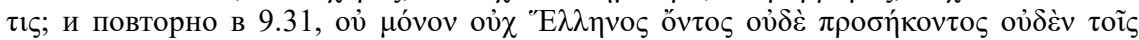

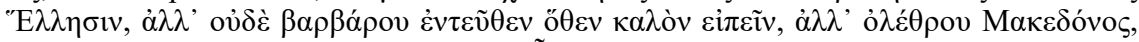

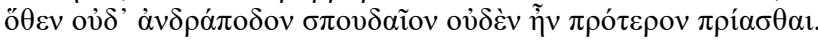

${ }^{26}$ Viz. Silva \& Albuquerque 2015: 349. Идентичность - это понятие, которое возникает скорее из того, как человек ведет себя и представляет себя перед обществом, чем из его истинного происхождения. Символический вид отдельного человека по которому узнают, носителя какой-то иднетичности: одежда, обычаи, язык, или какая-либо нибудь другая маркировка, которая имеет подсознательное влияние на процесс социализации, имеет черты, которые по своей природе перформативные. 
То же самое можно сказать и о других эпизодах. То, что Исократ говорит о происхождении македонского царского дома, служит определенной политической цели в данном историческом контексте, а именно речь, с которой пытается убедить Филиппа II выступить против Персии, вместо продолжать борьбу против эллинов. ${ }^{27}$ Исократ принимает притязания Филиппа на эллинизм и, со своей стороны, настаивает на том, что все они «одно и то же» и что они разделяют моральную ответственность за свои действия, поскольку для грека стыдно воевать против греков, особенно когда скрывается общий враг. С другой стороны, Демосфен не занимается суптильными политическими подходами. У него простое намерение: убедить афинян сражаться с Филиппом из-зо всех сил, а наиболее очевидная тактика для этого - изгнать Филиппа из рядов греков. Филипп II расширил македонский контроль вокруг своей окрестности и, тем самым вступил в конфликт с Афинами и другими эллинскими полисами. Чем больше входил в эллинскую политику и становился сильнее, тем больше росла ненвисть к нему. Реакция этому были голоса, которые твердили, что македонцы не эллины, а варвары, становились все сильнее, а особенно среди афинских политических ораторов того времени. Тактика не была плоха: так как Филипп II варвар, то он не только становится чужим, но и цель нападения на него оправдана.

Очень интересна одна деталь. Демостен мог выйти публично с такой позицией, и с надеждой, что кого-нибудь можно убедить, а никому, например, не приходило в голову подтердить - хотя бы в воинственной политической речи - что спартанцы, фиванцы или

Сущность этого перформативного перформанса могла быть предопределена доминирующей группой, как это было во время римских завоеваний: покоренные племена и народы, либо путем принуждения, либо потому что ожидали выгоды, пытались идентифицировать себя с завоевателями, чтобы узнать их язык и их эстетических концепциях; этим они приблизились к римской идентичности и, наконец, приняли ее.

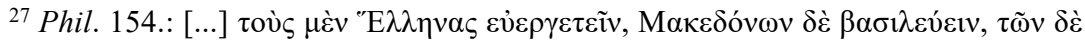

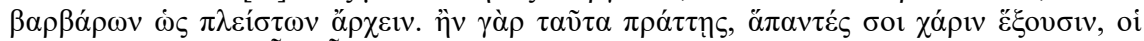

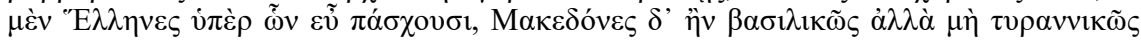

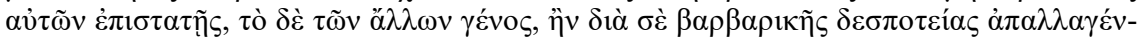

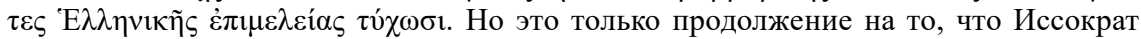

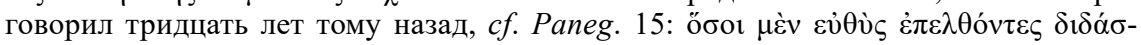

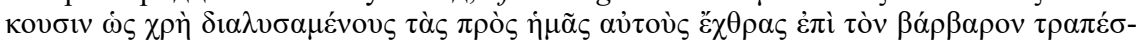
$\theta \alpha 1$, etc. Чесно говоря в Paneg. 125-6, хотя он крайне неприятельски настроен к Аминту, Иссократ делает отличие между ним и «варварским царем»: А $\mu v ́ v \tau \alpha \underline{\alpha} \delta \bar{\varepsilon} \tau \tilde{\omega}$

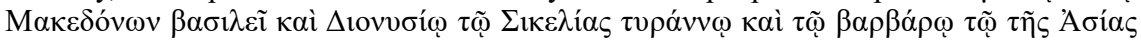

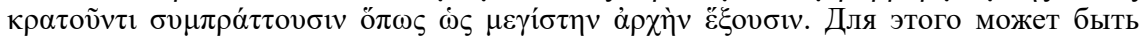
несколько причин: либо понятие варвара колеблется у Исократа, что не является чем-то необычным для других авторов, либо к тому времени «царь Азии» был архетипом варвара, как прежде был архетипом «великого царя»; в любом случае это работа, достойная отдельной статьи. 
коринфяне не были эллинами. ${ }^{28}$ Как Демостен мог такое сделать? Потому что македонцы имели свою особенную идентичность, и что их образ жизни, их мировоззрение и их культурные ценности в классические времена сильно отличались от тех у классических эллинов. Во главе их государства стояла царская династия, во время, когда это было непривычно. Чтобы разобраться с соседями, они приглашали переводчика. Ко времени Филиппа они изначально были скотоводами, а не фермерами - и ни в коем случае не гражданами. Македонцы вообще не участвовали в политическом контексте и не осознавали, что представляют собой политическую группу граждан. Если мы теперь обратимся к детерминантам, с помощью которых Геродот определяет принадлежность к эллинизму, имеем право уточнить - какие это обычаи, язык, религия, общественное устройство, политическое мировоззрение и образ жизни, что македонцы разделяли с другими эллинами? В этом случае они дают почти однозначный ответ и на правдивый очень простой вопрос, скрытый за современными преследованиями призраков эллинизма и варварства, а именно: не какие из этих народов считались варварами, а какие из них считались дикарями. ${ }^{29}$ Соседи эллинов на Балканах, без исключения, не говорили на понятном языке, не имели местной письменной культуры, не уважали привычки современной городской жизни и, кроме того, вели серию военных столкновений с эллинами в качестве завоевателей или наемников. ${ }^{30}$ Если посмотреть с

28 Это относится даже и к эллинам наиболее далеких от «стандарта», какими были эпирцы. Эпир, западный сосед Македонии, может служить интересной параллелью в отношении (не) принадлежности к эллинизму и всех двусмысленностей этой (не) принадлежности к крайней северо-западной границе эллинского мира. Эпирская речь считалась простым и отсталым северо-западным эллинским диалектом, но никогда не ставилось под сомнение, была ли она эллинской или нет. Как и македонцы, так и эпирцы в классическое время все еще вели архаический образ жизни со старомодными, даже и суровыми обычаями, которые ясно отличались от существующего образа жизни юга. И снова, в отличие от древних македонцев, никто никогда не обсуждал эллинизм эпирцев.

29 По мнению некоторых, такой взгляд вдохновлен (или, по крайней мере, под влиянием) римского взгляда на мир, или, скорее, римского взгляда на мир за Дунаем; однако, $c f$. ниже о дихотомиии римляна/варвара. Вероятнее, что ростки концепции варвар/дикарь в европейском античном мире появляются после кельтского нашествия на Балканы, и особенно после нападения на Дельфы. С этой точки зрения, весьма понятно, что эллины и македонцы оказались вместе по другую сторону этой дихотомиии, а Аталиды позже использовали победу над кельтами, чтобы представить себя спасителями цивилизации. Подробнее у S. Mitchell. "The Galatians: Representation and Reality". In A. Erskine (ed.), A companion to the Hellenistic world, Blackwell, 2003, 280-293.

30 Аналогично, в городских и дворцовых обществах Месопотамии чужой (дикарь / «варвар») - это кочевник, который не знает «достижений цивилизации» (образ жизни в крупных городских центрах), который не возделывает полей, не ест приготовленную пищу, который ведет себя (и выглядит) как животное и говорит странным и запутанным образом. Это описывает, например, кутийцев, которые несли ответственность за свержение империи Саргонидов («выглядят как обезьяны») или, столетия спустя, амореев («едят живое мясо, не знают о домах, не 
этой стороны, то тяжело было бы обычному афинянину $\mathrm{V}$ века до н.э. видеть что-то другое, кроме дикарей. И то, что проблема носит политический характер и проистекает из интересов политической сцены на южных Балканах, подтверждается еще одной важной деталью: в большинстве источников обсуждается этническая принадлежность македонского королевского дома, а не македонџь как этническая общность. Помимо этнической принадлежности королевского дома как политического и экономического фактора, никто не занимается этнической принадлежностью подданных; складывается впечатление, что это не имеет значения для источников, а знание мотивов некоторых из них - вероятно, действительно не имело.

Из всего этого следует вывод, что никакие выдержки из древних источников не приведут нас к истине. Мы не обсуждаем объективные детали жизни и общества древних македонцев - насколько мы их обнаружили, истолковали и поняли - но взгляды некоторых древних писателей, которые не можем утверждать (а у нас есть больше оснований сомневаться) что отражают взгляды и верования всех македонцев или всех эллинов в классические времена. Мы пытаемся доказать историческую правду, используя стереотипные риторические аргументы, которые не говорят нам что на самом деле эллины думали о македонском королевском доме, не говоря уже о народе или о том, как македонцы себя чувствовали.

4. Подходим к части, которая особенно важна для некоторых историков древности; потому что вопрос, к которому сводится дискуссия - насколько можно свести к обсуждению современных этносов и национальностей - не в том, были ли македонцы эллинами, а в том, был ли Александр эллином и считался ли он таковым эллинами. Это правда, что эллинам было намного легче принять Александра как эллина. Он знал аттический диалект, получил образование у Аристотеля, читал Гомера и трагиков, приносил публичные жертвы эллинским богам и проводил публичную политику, в которой он считал эллинское мировоззрение - продвигая, например, историю предполагаемой мести за зверства персов. ${ }^{31}$ Несмотря, он также считал македонцев чем-то отличным от эллинов. Во время его

знают о похоронных обычаях»). На Древнем Востоке дикарь / «варвар» также чужд на многих уровнях - с политической, культурной и даже, наконец, с этнической точки зрения.

${ }^{31}$ В этом не было ничего нового, но в тот момент это привлекло внимание широкой (эллинской) аудитории. В остальном, хотя они считались символами македонского государства, короли, королевская семья и высшая знать были в то же время, возможно, «самыми эллинизированными» людьми в Македонии. Пеллу часто посещали известные эллинские ученые, художники и творцы, такие как поэты Пиндар и Вакхилид, трагики Еврипид и Агафон, эпический поэт Хойрил, живописец Зевксид и музыкант Тимофей. Сближение королевского дворца с эллинскими стандартами началось во времена Архелая в V веке до нашей эры и набирало обороты с каждым поколением, достигнув высшей точки во времена Филиппа II и Александра III. 
завоеваний, хотя македонцы верно следовали за своим царем, большинство эллинов, которые не считались его подданными, были скорее заложниками, чем настоящими союзниками; и почти все колонии которые основал изначально состояли из ветеранов войны из Македонии, а не из эллинов.

Насколько нам известно, Александр Великий не послушал совета Аристотеля, относиться по-другому к эллинам, а по-другому к варварам - к одним, как к родным и приятелям, а к другим, как к слугам, а Эратосфен позже хвалил его именно за такое правильное отношение. $^{32}$ стали доступны всем, независимо от происхождения или принадлежности, потому что они воспитывались на основе определенного непредубежденного, философского образования и мировоззрения. Принадлежность к варварам или эллинам очень быстро стала вопросом образования и гражданства, ${ }^{33}$ к радости некоторых философов того времени, которые ранее отвергали разделение людей на эллинов и варваров, свободных и рабов. ${ }^{34}$

5. Общественные и политические события после смерти Александра Великого усложняют эту историю. Политически, значимо, но также как организованные группы с определенным мировоззрением - ни македонцы не были теми македонцами времен Грекоперсидской и Пелопоннесской войн, ни эллины не были такими же эллинами из классических времен и из зенита полисного мира. Восприятие македонцев и эллинов необратимо изменилось. «Восточные», неевропейские народы, попавшие под власть македонских диадохов и эпигонов, даже не пытались проникнуть в различия между завоевателями с запада, поэтому они обычно группировали их вместе. ${ }^{35}$ В новых поселениях и новых армиях эллинистического

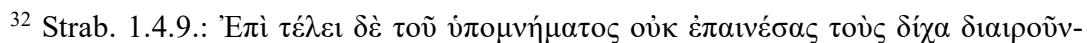

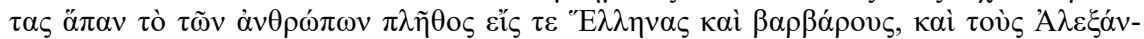

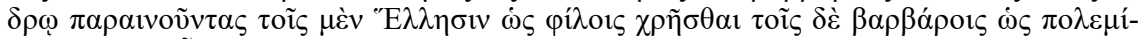

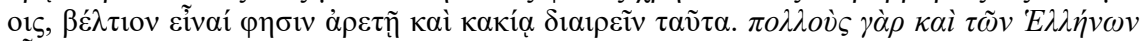

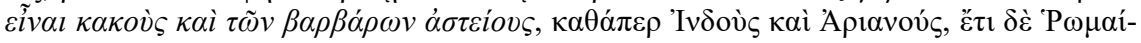

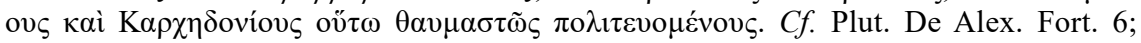
Arist. Pol. 1.8; 7.7. V. García Gual 1999: 72.

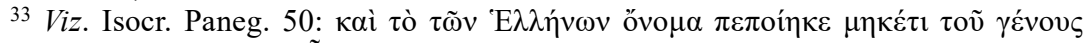

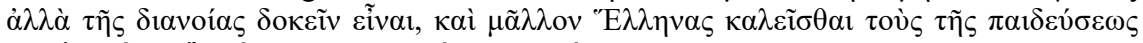

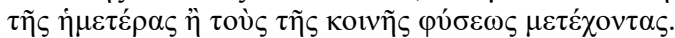

${ }^{34}$ Но также и заговорщикам панэллинизма, который в то время был скорее риторически-философской платформой, чем идеологией политического действия; $v$. Flower 2000, 65; Perlman 1976, 4. Тем не менее, следует обратить внимание на отношение Александра и эллинизма, и наоборот, на отношение эллинских философов и Александра; не все мысли шли в одном направлении. В качестве примера упомняем Элия Аристида, который во II веке н.э. считает, что, несмотря на привлекательную силу «эллинского» Александра, гордость эллинов вовсе не обязана полагаться на историю Македонии, а должна настаивать либо на «греко-римском» Александре, либо на Риме как высшем достижении полисной культуры. Больше у Asirvatham 2006; $c f$., так же, и Рeirano 2010.

35 Это обычная практика, которая случалась и прежде, и позже. Например, персы называют все народы вокруг Эгейского побережья - Yauna, «ионцы»; а 
Востока македонцы и эллины обычно присоединялись к одной и той же вербовочной группе. Ранее отличавшиеся от эллинов по многим критериям, во времена эллинизма (а фактически со времен Филиппа II) часть македонцев стала разделять с эллинами образование, мировоззрение, привычки и повседневную жизнь. В колониях, основанных наследниками Александра по всей Азии, начали течь эллины с различной местной идентичностью, настолько, что мы уже не можем различать, кто переехал, когда и откуда. Можно сказать, что эти эллины в Азии стали почти первыми «генерическими» эллинами; ${ }^{36}$ они первыми заговорили об общем стандартизированном эллинском диалекте koine, который со временем вытеснил все другие диалекты в повседневном общении. ${ }^{37}$ Эта koine вошла во все поры общества до такой степени, что до прихода римлян во многих местах мы больше не можем восстанавливать первоначальный диалект, потому что у нас нет письменных свидетельств этого. Проблема с письменными свидетельствами особенно остро ощущается в Македонии (но также во Фракии и Иллирии), где этот диалект стал официальным языком царских документов, а от предыдущих языков вряд ли можно найти письменный след.

Проблема слияния народов в царства диадохов и эпигонов не так проста, как ее обычно представляют. Спустя более полутора веков после завоевания большинство завоеванных восточных народов в царствах Селевкидов и Птолемеев оставались отдельными; только среди подданных европейского происхождения (македонцы, эллины и фракийцы) очевидные и культурные различия начали исчезать, чего, честно говоря, никто на Востоке не пытался замечать. Одним местом, где эллины по-прежнему считали македонцев иностранцами, были Балканы, давняя родина двух народов, где эллины никогда не отказывались от старого повествования о том, что они находятся под иностранным правлением и что им следует бороться за свою свободу.

Все это возвращает нас к исходному вопросу, но на этот раз в контексте античности, которая не является ни короткой, ни моно-

позже в средние века во всех источниках христиане назывались Франками, а мусульмане - сарацинами, без никакой попытки различать идентичность.

36 Процесс мог идти в двух направлениях. С одной стороны Платон боялся, что эллины из Сицилии перейдут на локальные языки и традиции (Ep. 8.353e:

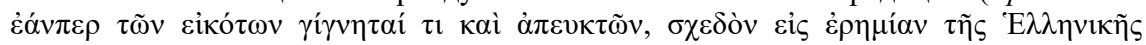

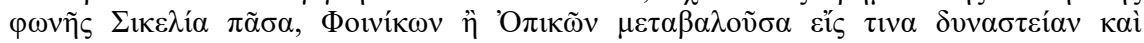

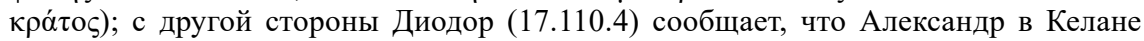
нашел некоторых бойотийцев, которые жили там со времен Ксеркса, но все еще

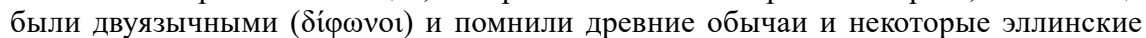

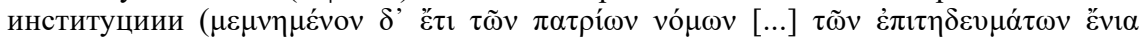
$\delta 1 \varepsilon \varphi v ́ \lambda \alpha \tau \tau o v) . V$. Nenci \& Cataldi 1983: 581.

${ }^{37} \mathrm{O}$ проблемах создания, а особенно расширения koine и подавления местных диалектов, v. F. Rodriguez-Adrados. A history of the Greek language from its origins to the present. Brill, Leiden-Boston, 2005, 176 sqq. 
литной, ни органически последовательной, а длится сотни лет, в которых происходят десятки исторических процессов. Каких именно македонцев мы сравниваем, и с какими эллинами? Македонцев с момента зарождения царства, до выхода на международную арену, македонцев Александра I, Филиппа II, или македонцев которые были подданными династии Антигонидов? И с какими эллинами - с теми, которые воевали против персов, с теми, которые жили в царстве Селевкидов, или с теми, которые пригласили императора Нерона на Олимпийские игры?

6. Вот, где скрывается ошибка в идеологически окрашенном нарративе, который отрицает принять во внимание, что имена, места и народы одного периода нельзя просто наклеить на что-то, что относится к другому периоду, а меньше всего в наше время. Культурная среда на Балканах представляет собой смесь двух тысячелетий потока торговцев и поселенцев, внешних вторжений и завоеваний, политических и этнических потрясений, которые изменились и меняют свой облик по сей день. Возможно, что некоторые изолированные общины оставались стабильными на протяжении всех потрясений; но в целом то, что нам сегодня кажется этнически однородным населением в рамках любого современного балканского государства, представляет собой простой набор региональных идентичностей, связанных сравнительно недавним территориальным объединением и пропитанных национальным нарративом.

Основная методологическая проблема таких взглядов на историю заключается не в том, что они приравниваются к чему-то, что для них на самом деле является лишь сновидением, а в том, что они верят в то, (1) что этничность может быть точно определена в древности, и (2) что она может установить чистую и прямую связь между древним народом - будь то эллины, фракийцы, иллирийцы или македонцы - и современными балканскими народами. А правда в том, что истоки сегодняшних балканских народов нельзя проследить по прямой линии ни от Цезаря, ни от Александра, ни от Перикла, и чем дальше мы идем в прошлое, тем бессмысленнее становится преследовать призраков этнической принадлежности и ее преемственности.

Допустим, для целей нашего обсуждения, что современные греки являются прямыми преемниками древних эллинов; это опять же не решит проблемы, заключающейся в том, что в древнем мире не было предписанной эллинской этнической принадлежности. Общее происхождение было важно для определенных групп в эллинском мире, но эллинизм сам по себе не определялся рождением. Выше мы видели, что эллины определили свою группу через общий язык, обычаи, богов, ритуалы и фестивали - это означает, что любого можно было назвать эллином, если он вел себя и жил как эллин, и если другие признавали его таковым. Вопрос о том, была ли историческая фигура этническим эллином, становится совершенно 
бессмысленным, если этот эллинизм по своей природе не определяется этнической принадлежностью - и особенно когда не существует древней этнической принадлежности, которую можно было бы однозначно идентифицировать и проследить в течение следующих 2500 лет. Кульминацией проблем является то, что все сегодняшние определения древних македонцев никоим образом не отделены от той бинарной системы этнической принадлежности, в которой вы либо эллин / македонец / фракийец / иллириец, либо нет, тогда как древняя реальность была несравненно более сложной.

Бесспорно, что образ варвара, а также контакты и отношения с не-эллинскими культурами, играли ключевую роль в формировании культуры и мировоззрения эллинов. Но мы часто подходим к этой проблеме таким образом, который вовсе не показывает специфический самореференциальный способ, которым эллины общались с другими; а удобная концепция бинарного мира (эллин / варвар; эллин / македонец; европеец / азиат; олигарх / демократ) вообще не принимает во внимание то, что эти категории содержат гораздо больше нюансов, чем пресловутый «другой», который когда-то заполнил современную гуманистику. ${ }^{38} \mathrm{~B}$ «Мифе о нациях» Патрик Гири нападает на ложную дихотомию римлян/варваров и пользуется этим положением для разрушения национальных мифов XIX века, прочно укоренившихся не только в прессе и популярной литературе, но и на университетском уровне. Он указывает на то, что римская идентичность была конституционной, созданной изнутри, на основе общей интеллектуальной культуры и традиции, правовой и политической системы и экономической традиции. Хотя были черты, которые делали римских граждан похожими, не было никакой «римской этнической принадлежности». С другой стороны, варвары были придуманной категорией, плодом долгой этнографической и дискурсивной традиции классического римского мира. Независимо от того, насколько римляне подчеркивали различия между двумя группами, принадлежность к одной категории не исключала другой; можно было быть и римлянином, и варваром одновременно; и если римлянин является вымышленной категорией, то же самое и с дикарем / варваром, который построен именно на основе римлянина как своего антипода. ${ }^{39}$

И ситуация с не полностью идентифицированными эллинами, колоритными варварами и древними македонцами не сильно отличается. Пора древним македонцам избавиться от балласта и давления вопроса об их этнической принадлежности. Биллоус утверждает, что сам вопрос прост, но на него трудно ответить, потому что идентичность древних македонцев находится в ловушке современной политики идентичности на Балканах; ${ }^{40}$ как мы видели на

\footnotetext{
38 Деталнее об этом у Vlassopoulos 2012: 66 sqq.

${ }^{39}$ Geary 2002: 81 sqq.

${ }^{40}$ Billows 2018: 8.
} 
предыдущих страницах, это не только не совсем правильно, но и сам этим питает то же заблуждение. Более серьезная проблема, чем политика, состоит в том, что вопрос поставлен методологически неверно и противоречит любому принципу исторического развития. Спорить об именах «эллины» и «македонцы»- это иллюзия, и совершенно неправильно различать их по существу, как если бы они были некой неизменной теоретической и эмпирической концепцией, существующей до нашего времени. На вопрос «какими были древние македонцы» есть только один обоснованный и твердый ответ - древние македонцы. Все остальное означало бы отрицание самой природы исторических процессов и попирание всех положений методологии исторической науки.

\section{ЛИТЕРАТУРА}

Asirvatham, S. R. "No Patriotic Fervor for Pella: Aelius Aristides and the Presentation of the Macedonians in the Second Sophistic". Mnemosyne 61.2 (2008), 207227.

Billows, R. A. Before and After Alexander: The Legend and Legacy of Alexander the Great. The Overlook Press, New York, 2018.

Buarque, L. "Gregos e Bárbaros no Político de Platão". Phoînix 24.1, (2018), 82-93.

Cartledge, P. “'We Are All Greeks'? Ancient (especially Herodotean) and Modern Contestations of Hellenism”. Bulletin of the Institute of Classical Studies, 1995, Vol. 40 (1995), 75-82.

Cartledge, P. The Greeks. A Portrait of Self and Others. Oxford University Press, 2002.

De Luna, M. E. La comunicazione linguistica fra alloglotti nel mondo greco. Da Omero a Senofonte. Studi e testi di storia antica 13. ETS, Pisa, 2003.

Engels, J. "Macedonians and Greeks". In Joseph Roisman \& Ian Worthington (eds.), A Companion to Ancient Macedonia, Wiley - Blackwell, 2010, 81-98.

Fabrício, A. R. \& Cunha, L. T. P. "Identidade e alteridade em Heródoto: visão de um Grego a respeito dos Egípcios". Alétheia. Revista de Estudos sobre Antiguidade e Medievo 9.1, 2014, 142-159.

Flower, M. A. "From Simonides to Isocrates: The Fifth-Century Origins of Fourth-Century Panhellenism". Classical Antiquity 19.1 (2002), 65-101.

García Gual, C. "Identidad y mitología. Apuntes sobre el ejemplo griego para una reflexión". Identidad humana y fin de milenio. Thémata 23 (1999), 69-80.

Geary, P. The Myth of Nations. Princeton University Press, 2002.

Giménez, G. "El debate contemporáneo en torno al concepto de etnicidad". Cultura representaciones soc 1.1 (2006), 129-144.

Goulart da Silva, M. "Bárbaros antigos ou modernos?" História, imagem e narrativas 6 (2008), 1-10. 
Gray, V. "Herodotus and the Rhetoric of Otherness". The American Journal of Philology 116.2 (1995), 185-211.

Hall, E. Inventing the Barbarian. Greek Self-Definition through Tragedy. Clarendon Press, Oxford, 1989.

Hall, J. M. Ethnic Identity in Greek Antiquity. Cambridge University Press, 1997.

Hall, J. M. Hellenicity. Between Ethnicity and Culture. University of Chicago Press, Chicago-London, 2002.

Hartog, F. The Mirror of Herodotus. The Representation of the Other in the Writing of History. University of California Press, 1988.

Hartog, F. Mémoire d'Ulysse. Récits sur la frontière en Grèce ancienne. Gallimard, Paris, 1996.

Isaac, B. "The Barbarian in Greek and Latin Literature". In Empire and Ideology in the Graeco-Roman World: Selected Papers. Cambridge University Press, 2017, 197-220.

Levy, E. "Herodote Philobarbaros ou la vision du barbare chez Herodote". In R. Lonis (ed.), L'Etranger dans le monde grec II, Actes du Deuxième Colloque sur l'Etranger. Presses Universitaires, Nancy, 1992, 193-244.

Malkin, I. The Returns of Odysseus. Colonization and Ethnicity. University of California Press, 1998.

Malkin, I. (ed.). Ancient Perceptions of Greek Ethnicity. University of Michigan, 2001.

Moggi, M. "Qualche riflessione su alterità e identità in Grecia (epoca arcaico-classica)". I Quaderni del Ramo d'Oro on-line 1 (2008), 54-72.

Nenci, G. \& Cataldi, S. "Strumenti e procedure nei rapporti tra Greci e indigeni". Modes de contacts et processus de transformation dans les sociétés anciennes. Actes du colloque de Cortone (24-30 mai 1981). École Française de Rome, 1983, 581-605.

Nenci, G. (ed.), 1990. Hérodote et les peuples non grecs. Neuf exposés suivis de discussions. Entretiens sur l'Antiquité Classique 35. Fondation Hardt, Genève, 1990.

Peirano, I. "Hellenized Romans and Barbarized Greeks. Reading the End of Dionysius of Halicarnassus 'Antiquitates Romanae'”. The Journal of Roman Studies 100 (2010), 32-53.

Perlman, S. "Panhellenism, the Polis and Imperialism". Historia: Zeitschrift für Alte Geschichte 25.1 (1976), 1-30.

Pontrandolfo, A. G. \& Rouveret A. "La rappresentazione del barbaro in ambiente magno-greco". In Modes de contacts et processus de transformation dans les sociétés anciennes. Actes du colloque de Cortone (24-30 mai 1981). École Française de Rome, 1983, 1051-1066.

Poutignat, P. \& Streiff-Fenart, J. Théories de l'ethnicité. Presses Universitaires de France, Paris, 1995.

Ross, S. A. "Barbarophonos: Language and Panhellenism in the Iliad". Classical Philology 100.4 (2005), 299-316.

Schirripa, P. "L'image grecque de la Thrace entre barbarie et fascination. Pour une remise en question". In I Traci tra geografia e storia. Aristonothos - Scritti per il Mediterraneo antico 9 (2015), 15-52.

Silva, D. G. G. \& Albuquerque, M. d. C. "Bárbaros ou/vs Romanos? Sobre Identidades e Categorias Discursivas". Mirabilia 21 (2015), 345-359.

Skinner, J. E. The Invention of Greek Ethnography. From Homer to Herodotus. Oxford University Press, 2012.

Vlassopoulos, K. "The Barbarian Repertoire in Greek Culture”. Ariadne 18 (2012), 5388. 